\title{
PERBANDINGAN INDEKS ERODIBILITAS TANAH YANG DITETAPKAN DENGAN METODE WISCHMEIER DAN RAINFALL SIMULATOR
}

\section{Comparison of Soil Erodibility Index Determined with Wischmeier and Rainfall Simulator Methods}

\author{
Sena Rizki Triyudanto, Zaenal Kusuma*, Istika Nita \\ Jurusan Tanah, Fakultas Pertanian, Universitas Brawijaya, Jl. Veteran no 1. Malang, 65145 \\ *Penulis korespondensi: kusumatnh@gmail.com
}

\begin{abstract}
Land use in the upstream area of the Brantas watershed, including that in Tawangsari village, Pujon District of Malang Regency, has undergone significant changes. The conversion of forest to moor, plantations, and settlements has resulted in decreased soil quality leading to soil degradation. The purpose of this research was aimed to compare the soil erodibility index determined by the rainfall simulator with Wischmeier methods. The results showed that there was a relationship between the results of the soil erodibility value using the Wischmeier method with land use and slopes based on the correlation and regression values caused by the physical properties of the soil. There were differences in soil erodibility index with the Wischmeier method and the Rainfall Simulator method, namely the average agroforestry results of 0.108 and 0.112 and an average of 0.152 and 0.147 moor. The use of the Wischmeier method is more recommended.
\end{abstract}

Keywords : land use changed, land degradation, rainfall simulator, soil erodibility, Wischmeier

\section{Pendahuluan}

Penggunaan lahan di kawasan DAS Brantas bagian hulu mengalami perubahan yang siginifikan. Desa Tawangsari merupakan salah satu desa di Kecamatan Pujon Kabupaten Malang yang berbatasan langsung dengan hutan alami yang memiliki beberapa jenis penggunaan lahan. Alih guna lahan hutan menjadi tegalan, perkebunan, dan pemukiman menyebabkan menurunnya kualitas tanah dan hal tersebut memicu terjadinya degradasi lahan di Desa Tawangsari. erosi merupakan salah satu potensi degradasi lahan yang diakibatkan oleh adanya alih guna lahan. Berdasarkan hasil penelitian sebelumnya oleh Hamam (2017) dengan jurnal yang berjudul "Analisis Potensi Bahaya Erosi di Sub DAS Mikro Hulu Brantas" menunjukkan bahwa potensi bahaya erosi tertinggi terdapat pada lahan dengan penggunaan sebagai ladang atau tegalan sebesar $126,36 \mathrm{t} \mathrm{ha}^{-1} \mathrm{th}^{-1}$, potensi erosi terendah ada pada lahan hutan sebesar 2,97 t ha ${ }^{-1}$ th $^{-1}$. Nilai erosi pada Sub DAS Mikro Hulu Brantas adalah 45,78 $\mathrm{t} \mathrm{ha}^{-1} \mathrm{th}^{-1}$, sementara perhitungan erosi yang diperbolehkan sebesar $13,23 \mathrm{t} \mathrm{ha}^{-1} \mathrm{th}^{-1}$. Peningkatan laju erosi setelah alih fungsi lahan disebabkan meningkatnya luas permukaan tanah yang terbuka dan terjadinya pemadatan tanah akibat gangguan mekanis, oleh karena itu diperlukan informasi mengenai nilai erodibilitas tanah pada Desa Tawangsari karena nilai erodibilitas tanah sangat penting untuk diketahui agar tindakan konservasi dan pengolahan tanah dapat dilaksanakan secara lebih tepat dan terarah. Erodibilitas tanah dipengaruhi oleh faktor-faktor seperti tekstur tanah, kandungan bahan organik, struktur tanah, dan permeabilitas tanah. Sifat fisik dan kimia tanah tersebut sangat dipengaruhi oleh penggunaan lahan di suatu daerah. Erodibilitas tanah adalah faktor penentu kehilangan tanah sehingga melalui erodibilitas tanah dapat diperkirakan laju erosi melalui karakteristik 


\section{Jurnal Tanah dan Sumberdaya Lahan Vol 8 No 2: 377-384, 2021 e-ISSN:2549-9793, doi: 10.21776/ub.jts1.2021.008.2.9}

tanah. Lebih lanjut Veiche (2002) menggambarkan sifat fisik, kimia, dan biologi tanah, serta mineral tanah dapat mempengaruhi nilai erodibilitas tanah. Adapun tujuan dari penelitian ini adalah mempelajari hubungan erodibilitas dengan penggunaan lahan dan kelerengan, mengetahui nilai erodibilitas tanah di berbagai penggunaan lahan dan kelerengan, serta akurasi dari penentuan nilai erodibilitas tanah menggunakan Rainfall Simulator dengan Wischmeier.

\section{Bahan dan Metode}

\section{Tempat, waktu dan bahan penelitian}

Pelaksanaan penelitian ini dilaksanakan pada bulan Maret 2020 hingga Juni 2020. Tempat penelitian terdapat di Desa Tawangsari, Kecamatan Pujon, Kabupaten Malang. Metode yang digunakan yaitu metode survei yang terbagi menjadi 3 tahapan yaitu tahapan pra-survei, suvei, dan pasca-survei. Penentuan titik beracuan pada penggunaan lahan, yaitu agroforestri dan tegalan. Terdapat 6 plot penelitian yang terdiri dari 2 penggunaan lahan yaitu agroforestri dan tegalan, masing-masing penggunaan lahan dibagi sesuai dengan kemiringan lahan yaitu $8-15 \%, 16-25 \%$, dan $>25 \%$. Pengamatan Rainfall Simulator dilakukan sesuai perlakukan pengamatan dengan 3 titik pengamatan setiap plot. Pengaturan intensitas curah hujan dilakukan sesuai kebutuhan pengamatan dalam liter per menit. Bahan yang digunakan dalam penelitian ini adalah Ring Sampel dan Ring Master, Cangkul dan Sekop, Klinometer, Pisau Lapang, GPS, Rainfall Simulator, Plastik, Label dan Spidol, Tali Rafia, Aquades, $\mathrm{H} 2 \mathrm{O} 2$, $\mathrm{H} 2 \mathrm{SO} 4, \mathrm{~K}_{2} \mathrm{Cr}_{2} \mathrm{O}_{7}$.

\section{Pelaksanaan penelitian}

Kegiatan pra-survei

Kegiatan pra-survei penelitian terdapat beberapa kegiatan seperti survei lapangan, penentuan lokasi pengambilan sampel, perizinan dengan pemilik, serta menyiapkan alat dan bahan untuk pengambilan sampel.

\section{Kegiatan survei}

Pada saat survei dilakukan pengambilan sampel tanah sesuai dengan perlakuan penelitian yaitu penggunaan lahan agroforestri atau penggunaan lahan tegalan dan kemiringan lereng yang berbeda sesuai dengan kriteria kemiringan 8$15 \%$, 16-25\%, dan $>25 \%$. Selanjutnya setelah menentukan penggunaan lahan yang ada pembuatan plot dengan ukuran $20 \mathrm{~m}$ x $20 \mathrm{~m}$ ditentukan pada masing-masing kriteria kemiringan lahan.

Kegiatan pasca-survei

\section{Metode Wischmeier}

Perhitungan nilai erodibilitas tanah (K) dilakukan dengan menggunakan data parameter tanah sebagai berikut: (1) persen kandungan tekstur (metode pipet), (2) persen bahan organic (metode Walkley dan Black), (3) permeabilitas (metode Constant Head Permeameter), dan (4) struktur tanah. Selanjutnya untuk mendapatkan nilai erodibilitas tanah, menurut Wischmeier dan Smith (1978) data yang telah diperoleh dihitung dengan menggunakan rumus:

$100 \mathrm{~K}=1.292\left(2.1 \mathrm{M}^{1.14}\left(10^{-4}\right)(12-\mathrm{a})+3.25(\mathrm{~b}-\right.$ 2) $+2.5(\mathrm{c}-3))$

\section{Metode Rainfall Simulator}

Pada penggunaan alat Rainfall Simulator, dilakukan pengamatan sediment yield pada masing-masing perlakukan dengan 3 kali ulangan. Kemudian dengan rumus perhitungan data erosi dari alat Rainfall Simulator dilakukan perhitungan dengan menggunakan rumus:

Erodibilitas $(\mathrm{K})=$ A/R.LS.CP

dimana:

$$
\begin{aligned}
\mathrm{A} & =\text { Erosi } \\
\mathrm{R} & =\text { Erosivitas (Curah } \\
\text { hujan) } & \\
\mathrm{LS} & =\text { Kelerengan } \\
\mathrm{CP} & =\text { Tanaman Penutup }
\end{aligned}
$$

\section{Analisis data}

Data yang telah didapatkan dari uji laboratorium kemudian diolah statistik menggunakan Ms. Excel dengan Uji-t berpasangan dengan taraf $5 \%$ untuk mengetahui apakah terdapat perbedaan yang nyata antara metode Rainfall Simulator dengan metode Wischmeier. 


\section{Hasil dan Pembahasan}

\section{Kondisi umum lokasi penelitian}

Desa Tawangsari terletak di sebelah barat laut dari wilayah Kecamatan Pujon. Ketinggian desa ini secara umum adalah $1100 \mathrm{~m}$ di atas permukaan laut. Curha hujan di desa ini rata-rata $2000 \mathrm{~mm}$ per tahun dan curah hujan tertinggi ada pada bulan November hingga April. Suhu rata-rata bervariasi tergantung ketinggian berkisar diantara $18-27^{\circ} \mathrm{C}$. Desa Tawangsari mempunyai luas wilayah desa sebesar 1424 ha yang terdiri dari bentang lahan perbukitan dan pegunungan, sawah, tegalan, hutan produksi, hutan lindung, perkebunan, dan pemukiman. Pada plot penelitian di Desa Tawangsari dibagi menjadi 2 penggunaan lahan, pada lahan agroforestri terdapat komoditas pohon eucalyptus, sedangkan pada lahan tegalan komoditas yang ada adalah tanaman bawang merah. Lokasi penelitian merupakan dataran tinggi dengan elevasi $>1000 \mathrm{~m}$ di atas permukaan laut. Kelerengan yang terdapat di lokasi penelitian terdiri dari kemiringan $8-15 \%$, $15-25 \%$, dan $>25 \%$.

\section{Bahan organik}

C-organik akan mempengaruhi kandungan bahan organik tanah, semakin tinggi kandungan C-organik maka semakin meningkat kandungan bahan organik. Kandungan bahan organik tanah dapat diketahui dari persamaan bahan organik $=$ \% C-organik x 1, 724 (Muklis, 2007). Dari Gambar 1. terlihat bahwa kandungan bahan organik pada penggunaan lahan agroforestri lebih tinggi disemua kelerengan dibandingkan dengan penggunaan lahan tegalan disemua kelerengan. Jumlah bahan organik tanah dipengaruhi oleh beberapa faktor, diantaranya adalah faktor penggunaan lahan dan pengolahan tanah. Pengaruh penggunaan lahan terkait dengan banyaknya sisa tanaman yang dapat disumbangkan ke dalam tanah dari tumbuhan yang berada di atasnya. Pengolahan tanah berpengaruh pada seberapa cepat bahan organik tanah itu terdekomposisi. Hasil menunjukkan bahan organik yang didapatkan pada penggunaan lahan hutan produksi lebih tinggi dibandingkan dengan penggunaan lahan yang lainnya. Hal ini sependapat dengan Bakri et al. (2016) menyatakan bahwa kandungan bahan organik tertinggi terdapat pada penggunaan lahan hutan yang memiliki lebih banyak seresah yang dapat terurai dan menjadi bahan organik tanah serta berfungsi sebagai perekat tanah yang nantinya dapat menahan tanah dari kehancuran akibat benturan air hujan. Purwanto et al. (2013) menyatakan bahwa semakin besar erosi maka kandungan bahan organik tanah menjadi semakin rendah.

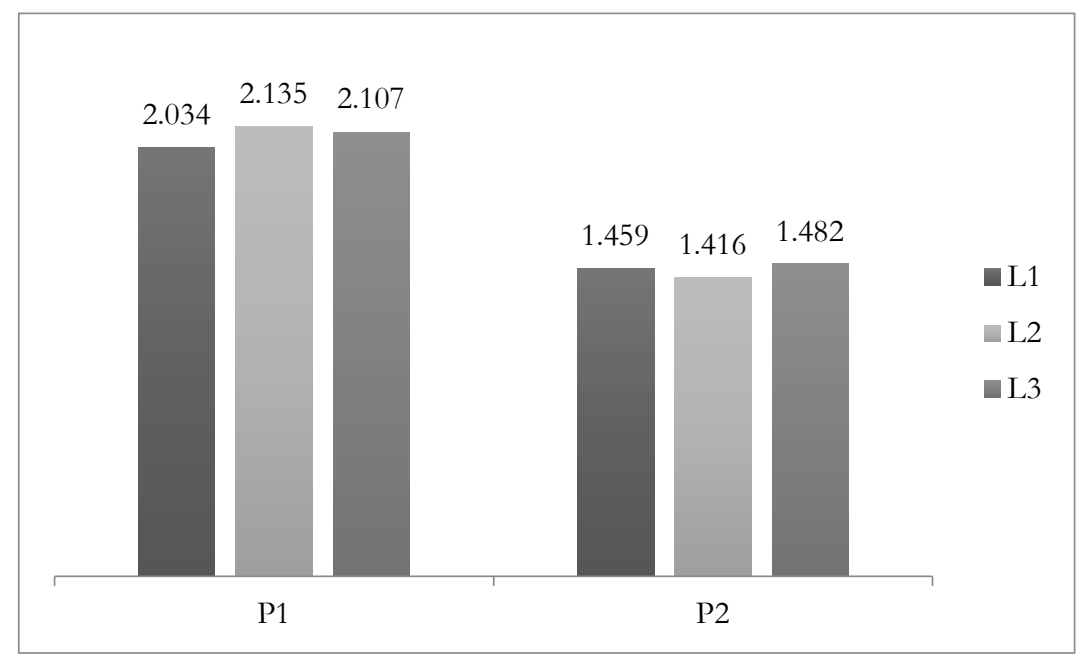

Gambar 1. Kandungan bahan organik tanah (\%). Keterangan: P1 = agroforestri; P2 = tegalan; L1 = kelerengan $8-15 \%$; L2 $=$ kelerangan $16-25 \%$; L3 $=$ kelerengan $>25 \%$.

\section{Struktur tanah}


Struktur tanah memengaruhi besarnya erosi. Tanah-tanah yang berstruktur granuler dan lebih terbuka akan menyerap air lebih cepat dari pada tanah yang berstruktur masif. Demikian pula peranan bahan organik penting terhadap stabilitas struktur tanah, karena bahan organik tanah berfungsi memperbaiki kemantapan agregat tanah, memperbaiki struktur tanah dan menaikkan daya pegang air tanah. Struktur tanah di lokasi penelitian sebagian besar jenis struktur tanahnya adalah gumpal membulat. Struktur tanah berhubungan erat dengan tekstur tanah, di mana partikel pasir, debu, dan liat relatif disusun satu sama lain yang kemudian membentuk suatu agregat. Struktur tanah gumpal membulat, memiliki ruang pori diantara partikel-partikel tanahnya, sehingga meningkatkan infiltrasi tanah yang memengaruhi erodibilitas tanah.

\section{Tekstur tanah}

Tekstur merupakan perbandingan relatif (dalam persen) fraksi-fraksi pasir, debu dan liat. Pada umumnya partikel partikel tanah terdiri dari komponen-komponen: liat $(<0,002 \mathrm{~mm})$, debu $(0,002-0,06 \mathrm{~mm})$, dan pasir $(0,06-2,0 \mathrm{~mm})$. Pada Gambar 2 diketahui bahwa pada semua penggunaan lahan agroforestri memiliki dominasi persen debu dibanding fraksi lain. Pada penggunaan lahan tegalan dengan kelerengan $8-15 \%$ didominasi fraksi debu, sedangkan pada kelerengan 16-25\% dan $>25 \%$ didominasi pasir dibandingkan dengan fraksi lain.

\section{Permeabilitas tanah}

Permeabilitas dapat mempengaruhi kesuburan tanah. Permeabilitas berbeda dengan drainase yang lebih mengacu pada proses pengaliran air saja, permeabilitas dapat mencakup bagaimana air, bahan organik, bahan mineral, udara, dan partikel-partikel lainnya yang terbawa bersama air yang akan diserap masuk kedalam tanah Gambar 3 menunjukkan permeabilitas pada penggunaan l;ahan yang berbeda. Menurut Mulyono et al., (2019) tanah dengan permeabilitas tinggi menaikkan laju infiltrasi dan dengan demikian, menurunkan laju air larian. Menurunya laju aliran permukaan ini dapat menyebabkan rendahnya nilai kepekaan tanah terhadap erosi karena air yang terdapat di lahan lebih banyak terserap kedalam tanah melalui peroses infiltrasi tanah.

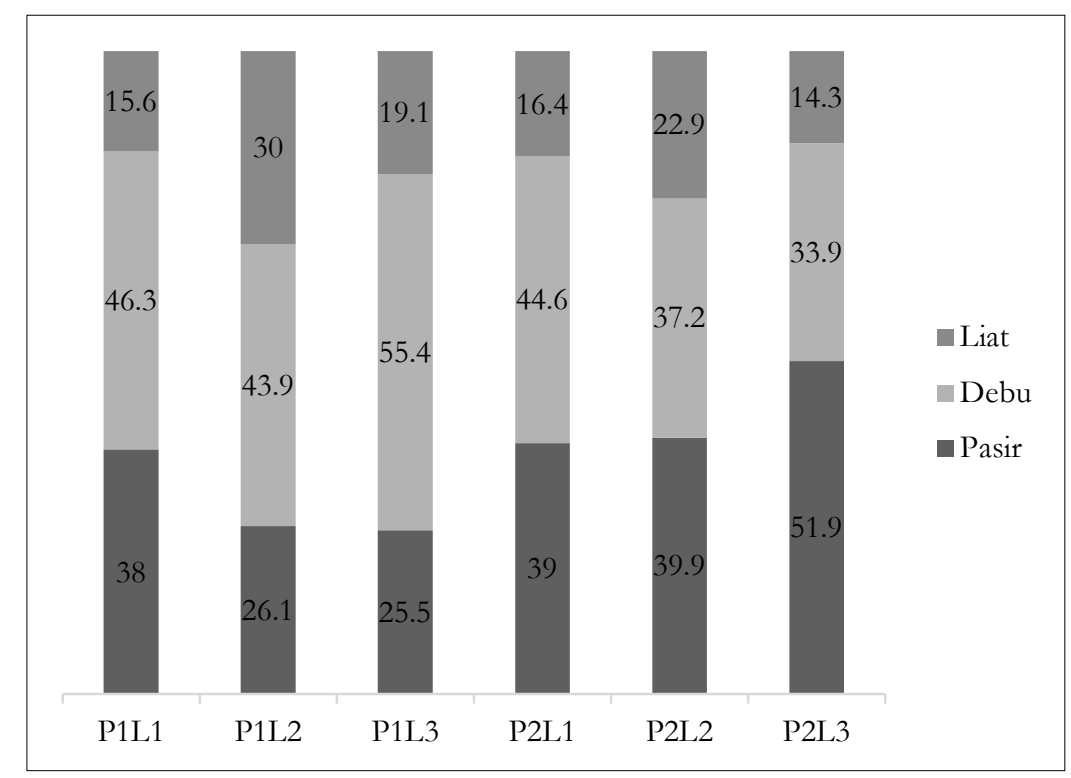

Gambar 2. Tekstur tanah (\% pasir, debu, liat). Keterangan: P1L1 = agroforestri 8-15\%; P1L2 = agroforestri 16-25\%; P1L3 = agroforestri $>25 \%$; P2L1 = tegalan 8-15\%; P2L2 = tegalan 16-25\%; P2L3 = tegalan $>25 \%$. 


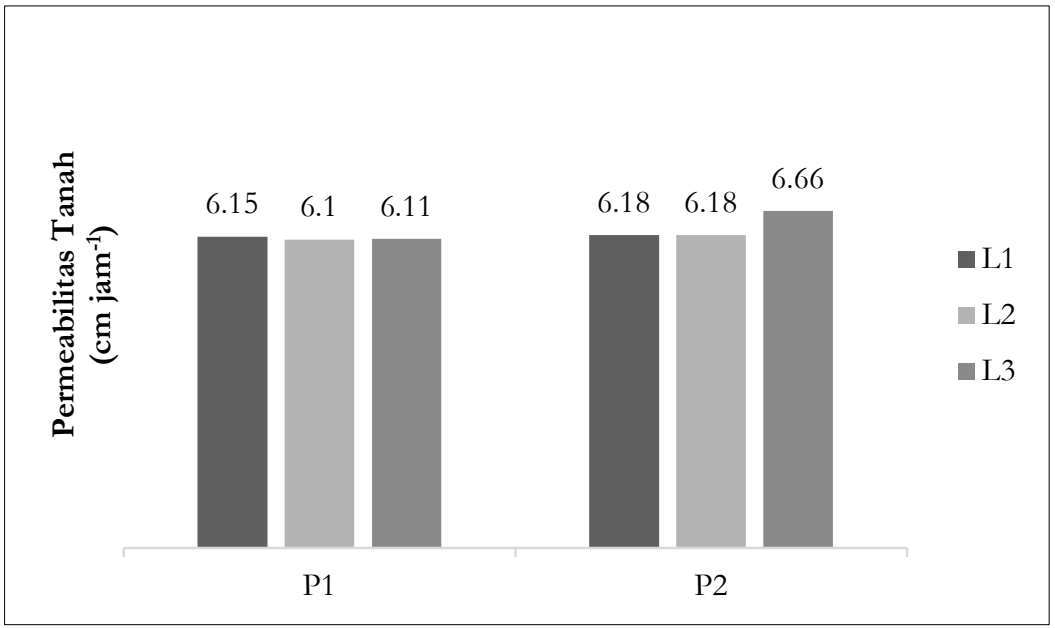

Gambar 3. Permeabilitas tanah $\left(\mathrm{cm}_{\text {jam }}{ }^{-1}\right)$. Keterangan: $\mathrm{P} 1=$ agroforestri; $\mathrm{P} 2=$ tegalan; $\mathrm{L} 1=$ kelerengan $8-15 \%$; L2 $=$ kelerangan $16-25 \%$; L3 = kelerengan $>25 \%$.

\section{Erodibilitas dengan metode Wischmeier}

Kepekaan tanah terhadap erosi atau disebut erodibilitas tanah didefinisikan sebagai mudah tidaknya tanah untuk dihancurkan oleh hujan. Perhitungan erodibilitas dengan metode wishcmeier memiliki 4 pertimbangan parameter yaitu tekstur (pasir, debu, dan liat), struktur tanah, bahan organik, dan permeabilitas tanah. Pada Gambar 4 terlihat perbedaan nilai erodibilitas tanah pada masing-msing penggunaan lahan. Nilai erodibilitas tanah pada penggunaan lahan agroforestri pada seluruh kelerengan lebih rendah dibandingkan dengan penggunaan lahan tegalan. Adanya perbedaan nilai erodibilitas ini salah satunya karena adanya perbedaan pada bahan organik dan intensitas pertanian pada lokasi penelitian. Agroforestri memiliki masukan bahan organik dari seresah pohon yang beragam dan banyak dibandingkan dengan tegalan. nilai erodibilitas berdasarkan perbedaan kelerengan pada penggunaan lahan agroforestri maupun tegalan paling besar nilainya pada kelerengan $>25 \%$ hal ini menurut Wenyi et al. (2014) kemiringan lereng akan mempengaruhi banyaknya limpasan yang terjadi, semakin besar nilai kemiringan lereng, maka tingkat erosi yang terjadi akan lebih besar dibandingkan dengan wilayah yang datar.

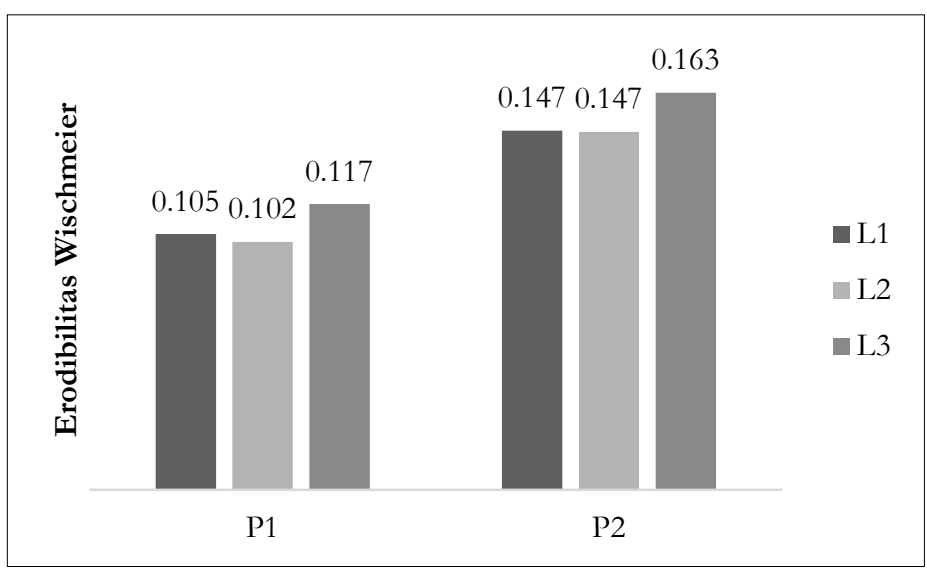

Gambar 4. Indek Erodibilitas tanah dengan metode Wischmeier. Keterangan: P1 = agroforestri; P2 $=$ tegalan; $\mathrm{L} 1=$ kelerengan $8-15 \%$; L2 $=$ kelerangan $16-25 \%$; L3 $=$ kelerengan $>25 \%$. 


\section{Erodibilitas dengan metode Rainfall Simulator}

Kepekaan tanah terhadap curah hujan dapat diukur juga dengan alat Rainfall Simulator dengan langsung dilakukan dilapangan. Parameter yang diukur dan diambil dari lapangan adalah sedimen yang ditampung saat dilakukan pengambilan sample. Dengan ukuran frame 26x27 $\mathrm{cm}^{2}$, curah hujan maksimum dan waktu 10 menit didapatkan hasil erodibilitas pada setiap penggunaan lahan. Faktor lereng dan curah hujan menjadi penentu utama dari hasil sedimen alat Rainfall Simulator. Pada Gambar 5. terlihat perbedaan hasil erodibilitas dari setiap penggunaan lahan denga kelerengan tertentu. Nilai erodibilitas tanah pada penggunaan lahan agroforestri lebih rendah dibandingkan dengan lahan tegalan. Hal ini sejalan dengan Oktiviani (2009) sifat fisik dan kimia tanah sedikitnya dipengaruhi oleh penggunaan lahan yang terdapat pada daerah tersebut.

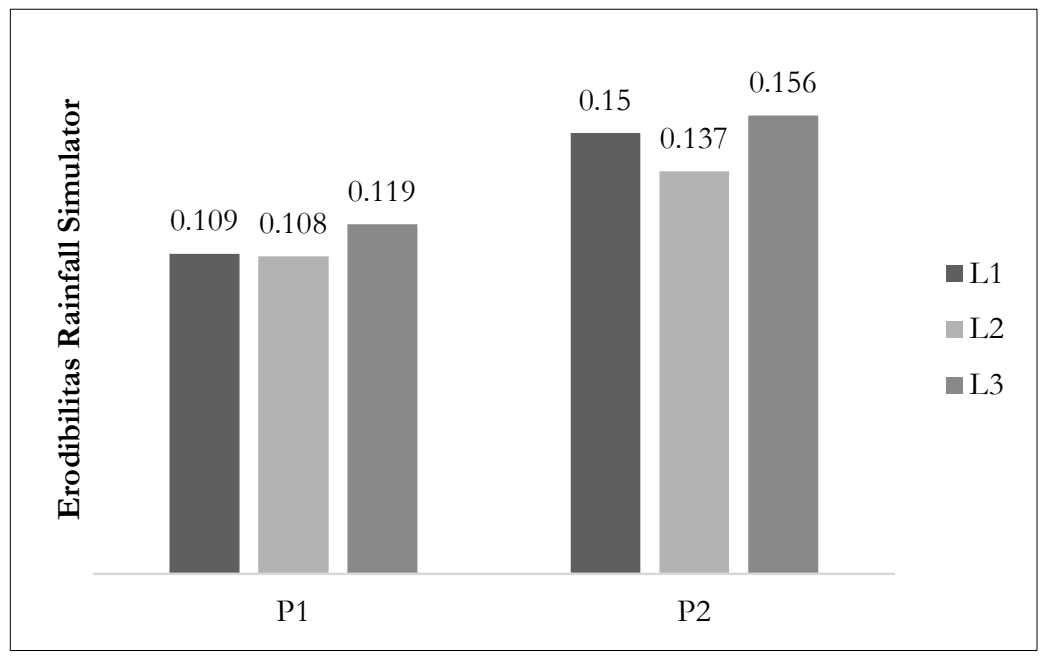

Gambar 5.Indek Erodibilitas tanah dengan metode Rainfall Simulator. Keterangan: P1 = agroforestri; P2 = tegalan; L1 = kelerengan 8-15\%; L2 = kelerangan 16-25\%; L3 = kelerengan $>25 \%$.

\section{Hubungan sifat fisika dan kimia tanah terhadap nilai erodibilitas}

Menggunakan hasil perhitungan erodibilitas dengan metode Wischmeier, dilakukan perhitungan korelasi dan regresi dengan sifatsifat fisika dan kimia tanah. Erodibilitas tanah dipengaruhi oleh banyak sifat-sifat tanah yaitu termasuk sifat fisika tanah yang merupakan unsur lingkungan yang sangat berpengaruh terhadap tersedianya air, udara tanah dan secara tidak langsung mempengaruhi ketersediaan unsur hara tanaman oleh sebab itu menurut Veiche (2002) sifat fisik tanah seperti tekstur, struktur, permeabilitas, dan termasuk karakterisitik profil tanah seperti kedalaman tanah akan memengaruhi erodibilitas tanah. Berdasarkan hasil uji regresi berganda yang disajikan pada Tabel 1, didapatkan nilai $\mathrm{r}=$
0,8954 hal ini menunjukkan keeratan hubungan antara metode Wischmeier dengan 5 variabel yaitu fraksi pasir, fraksi debu, fraksi liat, permeabilitas tanah dan bahan organik cukup kuat tanah karena nilai yang mendekati angka 1 . Hasil uji regresi berganda pada erodibilitas tanah dengan menggunakan metode Wischmeier menunjukkan hasil bahwa variabel paling kuat atau paling memengaruhi erodibilitas tanah adalah bahan organik tanah. Menurut Priatna (2011) bahan organik merupakan faktor yang besar pengaruhnya terhadap erodibilitas selain tekstur tanah. Hal ini antara lain karena bahan organik memiliki kemampuan menyerap dan menahan air yang tinggi, membantu perkembangan struktur tanah, serta menambah kesuburan sehingga berpengaruh terhadap keberadaan vegetasi yang tumbuh di atasnya (Arsyad, 2010). 


\section{Jurnal Tanah dan Sumberdaya Lahan Vol 8 No 2: 377-384, 2021 \\ e-ISSN:2549-9793, doi: 10.21776/ub.jts1.2021.008.2.9}

Tabel 1. Hasil uji regresi.

\begin{tabular}{ccccc}
\hline Variabel & $\mathbf{R}^{2}$ & Konstanta & Koefisien & Model Persamaan \\
\hline Pasir & & & 0,000221 & $\mathrm{Y}=0,3314+$ \\
Debu & & & 0,000193 & $0,00022 \mathrm{x}_{1}+0,00019 \mathrm{x}_{2^{-}}$ \\
Liat & 0,8017 & 0,3314 & $-0,000781$ & $0,00078 \mathrm{x}_{3}-0,0184 \mathrm{x}_{4^{-}}$ \\
Permea & & & $-0,018473$ & $0,0493 \mathrm{x}_{5}$ \\
BO & & & $-0,049319$ & \\
\hline
\end{tabular}

Keterangan: $\mathrm{Y}=$ erodibilitas; $\mathrm{X} 1=$ pasir; $\mathrm{X} 2=$ debu; $\mathrm{X} 3=$ liat; $\mathrm{X} 4=$ permeabilitas; $\mathrm{X} 5=$ bahan organik.

\section{Perbandingan akurasi erodibilitas}

Hasil perhitungan nilai erodibilitas antara metode Rainfall Simulator dengan wischmeier memilki hasil yang relatif serupa disemua penggunaan lahan dan semua kelerengan. Uji T Berpasangan dengan probabilitas $5 \%$ didapatkan hasil t-hitung lebih kecil dari t 0.862 $<2.570$ bermakna hasil dari kedua metode penentuan nilai erodibilitas ini tidak berbeda jauh sehingga dapat dinyatakan bahwa kedua metode penentuan ini memiliki akurasi yang baik dan dapat dipertahankan secara ilmiah. Hal ini bisa karena komponen dari perhitungan wischmeier mempertimbangkan tekstur, struktur, permeabilitas, dan bahan organik sedangkan Rainfall Simulator memiliki komponen hasil dari curah hujan secara langsung yaitu sediment yield. Asdak (2010) menjelaskan bahwa dalam sistem hidrologi karakteristik daerah aliran sungai (DAS) terkait dengan unsure-unsur seperti iklim, jenis tanah, tata guna lahan dan topografi

\section{Kesimpulan}

Berdasarkan hasil perhitungan dan analisis didapatkan kesimpulan penelitian yaitu hasil nilai erodibilitas menggunakan metode Wischmeier dengan penggunaan lahan dan kelerengan menunjukan hasil korelasi sangat kuat dengan nilai $r=0,895$. Pengukuran indeks erodibilitas dengan metode Wischmeier dan metode Rainfall Simulator memiliki perbedaan, yaitu dengan hasil rata-rata Agroforestri 0,108 dan 0,112 dan rata-rata Tegalan 0,152 dan 0,147. Serta nilai erodibilitas yang dihasilkan dari metode Rainfall Simulator dan Wischmeier tidak memiliki perbedaan yang nyata, dibuktikan dari uji t Berpasangan taraf 5\% didapatkan hasil $\mathrm{T}$ hitung 0,862 <2,570 t tabel. Namun, dalam pelaksaannya Rainfall Simulator bergantung pada curah hujan yang disimulasikan, sehingga metode Wischmeier lebih disarankan.

\section{Ucapan Terima Kasih}

Penulis mengucapkan terima kasih kepada petani pemilik lahan di Desa Tawangsari, Kecamatan Pujon, Kabupaten Malang, atas perkenan penggunaan lahannya untuk penelitian ini.

\section{Daftar Pustaka}

Arsyad, S. 2010. Konservasi Tanah dan Air. Edisi kedua. IPB Press. Bogor. pp 110-121.

Asdak, C. 2010. Hidrologi dan Pengelolaan Daerah Aliran Air Sungai: Edisi. Revisi Kelima. Yogyakarta: Gadjah Mada University Press Yogyakarta.

Bakri, I., Thaha, A. R. dan Isrun. 2016. Status Beberapa Sifat Kimia Tanah Pada Berbagai Penggunaan Lahan Didesa Poboyo Kecamatan Palu Slatan. Fakultas Pertanian Universitas Tadulako. P 16

Hamam, A. 2017. Analisis Potensi Bahaya Erosi di Sub DAS Mikro Hulu Brantas. UMM. Malang

Muklis. 2007. Analisis Tanah dan Tanaman. USU press, Medan.

Mulyono, A., Lestiana, H. dan Fadilah, A. 2019. Permeabilitas tanah berbagai tipe penggunaan lahan di tanah aluvial pesisir DAS Cimanuk, Indramayu. Jurnal Ilmu Lingkungan 17: 1-6.

Oktiviani, F. 2009. Pengaruh Penggunaan Lahan terhadap Sifat Fisik Kimia dan Erodibilitas Tanah Pada Berbagai Kemiringan Lereng. Fakultas Pertanian. Institut Pertanian Bogor. PP 12-48.

Priatna, S.J. 2011. Indeks Erodibilitas dan Potensi Erosi pada Areal Perkebunan Kopi Rakyat Dengan Umur dan Lereng yang Berbeda. Jurnal Ilmu-Ilmu Pertanian Indonesia 3 (2): 84-88.

Purwanto, Sukresno, Cahyono, S.A., Irawan, E. dan 


\section{Jurnal Tanah dan Sumberdaya Lahan Vol 8 No 2: 377-384, 2021 \\ e-ISSN:2549-9793, doi: 10.21776/ub.jts1.2021.008.2.9}

Yuliantoro, D. 2013. Nilai ekonomi erosi tanah Ultisols (studi kasus di sub DAS Ngunut, Desa Ngunut,

Veiche, A. 2002. The spatial variabelity of erodibility and its relation to soil types. a study from Northern Ghana. Geoderma 106: 110-120.

Wenyi, S., Quanqin, S., Jiyuan, L. and Jun, Z. 2014. Assessing the effects of land use and topography on soil erosion on the Loess Plateau in China. Catena 121: 151-163, doi: 10.1016/j. catena.2014.05.009.
Wischmeier, W.H. and Smith, D.D. 1978. Predicting rainfall erosion losses - a guide to conservation planning. U.S. Department of Agriculture, Agriculture Handbook No. 537. 